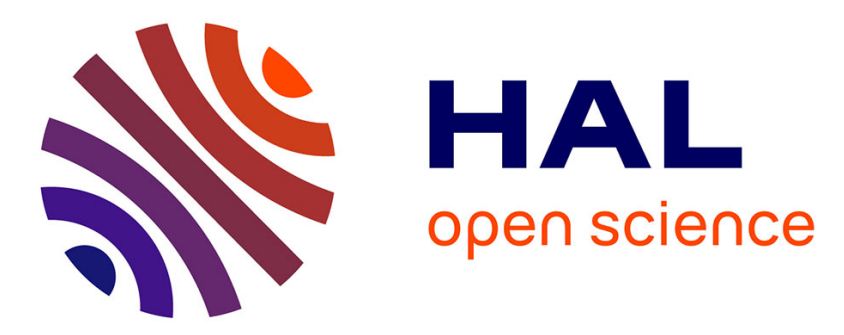

\title{
ORIGIN OF THE INFRARED ABSORPTION IN LaMgAl11O19 : Ti3 + A POTENTIAL LASER MATERIAL
}

\author{
B. Martinat, A. Lejus, D. Vivien
}

\section{- To cite this version:}

B. Martinat, A. Lejus, D. Vivien. ORIGIN OF THE INFRARED ABSORPTION IN LaMgAl11O19: Ti3+ A POTENTIAL LASER MATERIAL. Journal de Physique IV Proceedings, 1991, 01 (C7), pp.C7-343-C7-345. 10.1051/jp4:1991791 . jpa-00251034

\section{HAL Id: jpa-00251034 https://hal.science/jpa-00251034}

Submitted on 1 Jan 1991

HAL is a multi-disciplinary open access archive for the deposit and dissemination of scientific research documents, whether they are published or not. The documents may come from teaching and research institutions in France or abroad, or from public or private research centers.
L'archive ouverte pluridisciplinaire HAL, est destinée au dépôt et à la diffusion de documents scientifiques de niveau recherche, publiés ou non, émanant des établissements d'enseignement et de recherche français ou étrangers, des laboratoires publics ou privés. 


\title{
ORIGIN OF THE INFRARED ABSORPTION IN LaMgAl $11 \mathrm{O}_{19}: \mathrm{Ti}^{3+}$ A POTENTIAL LASER MATERIAL
}

\author{
B. MARTINAT, A.M. LEJUS and D. VIVIEN \\ Chimie Appliquée de l'Etat Solide, URA 1466 ENSCP, 11 rue Pierre et Marie Curie, \\ F-75231 Paris cedex 05, France
}

\begin{abstract}
The $\mathrm{LaMgAl}_{11} \mathrm{O}_{19}$ matrix (magnetoplumbite structure) activated with $\mathrm{Ti}^{3+}$ could present broadly tunable laser action between 650 and $1000 \mathrm{~nm}$. The optical absorption measurements show, in addition to the ${ }^{2} \mathrm{~T}_{2} \rightarrow{ }^{2} \mathrm{E}$ transition of $\mathrm{Ti}^{3+}$, two unexpected infrared bands. The first one, peaking at $730 \mathrm{~nm}$, is attributed to an intervalence charge transfer transition of $\mathrm{Ti}^{3+}-\mathrm{Ti}^{4+}$ pairs located in (4f) sites. The second one, at $960 \mathrm{~nm}$, is attributed to a $\mathrm{Ti}^{2+}-\mathrm{Ti}^{3+}$ charge transfer transition. These bands which occur in the range of the $\mathrm{Ti}^{3+}$ fluorescence wavelengths have to be suppressed for the lasing application of this material.
\end{abstract}

The $\mathrm{LaMgAl}_{11} \mathrm{O}_{19}$ hexaaluminate (LMA), with magnetoplumbite like structure, is well known as a remarkable good laser host. When the activator is $\mathrm{Nd}^{3+}$, one obtains LMA:Nd or LNA, which has been widely studied (1)(2). This work deals with the activation of this matrix with $\mathrm{Ti}^{3+}$ ions which could present broadly tunable laser action between 650 and $1000 \mathrm{~nm}$ like Ti doped sapphire (3).

Single crystals of $\mathrm{LaMgAl}_{11-\mathrm{x}} \mathrm{Ti}_{\mathrm{x}} \mathrm{O}_{19}$ are grown by flame fusion process (Verneuil method). In the matrix, Ti can be inserted in 3+ and 4+ oxidation state or in a mixture of both states. Traces of $\mathrm{Ti}^{2+}$ might be present. Previous ESR studies have demonstrated that $\mathrm{Ti}^{3+}$ is localized in the 3 octahedral sites (2a) (12k) (4f) of the structure with a strong preference for the (2a) site. $\mathrm{Ti}^{2+}$ would be situated in the (4f) site, the largest octahedral site (4). Compared to Ti: sapphire, there is no segregation of the doping ion and titanium solubility is much larger.

The optical absorption measurements (5) exhibit, in addition to an intense band peaking at $570 \mathrm{~nm}$ attributed to the ${ }^{2} \mathrm{~T}_{2} \rightarrow{ }^{2} \mathrm{E}$ transition of $\mathrm{Ti}^{3+}$, unexpected bands in the infrared. This is shown in figure 1 where the diffuse reflectance spectrum, performed on ground crystals, can be fitted as a sum of three Gaussian bands centered at 730, 960 and $1240 \mathrm{~nm}$. We have only considered the two main bands at 730 and $960 \mathrm{~nm}$ with the aim to determine their origin and to try to suppress them. In fact, these bands occur in the range of the $\mathrm{Ti}^{3+}$ fluorescence wavelengths and they may have desastrous consequences for the laser application of this material.

From the behavior and the polarization of these bands, several hypotheses have been proposed (see Table I) (5) 


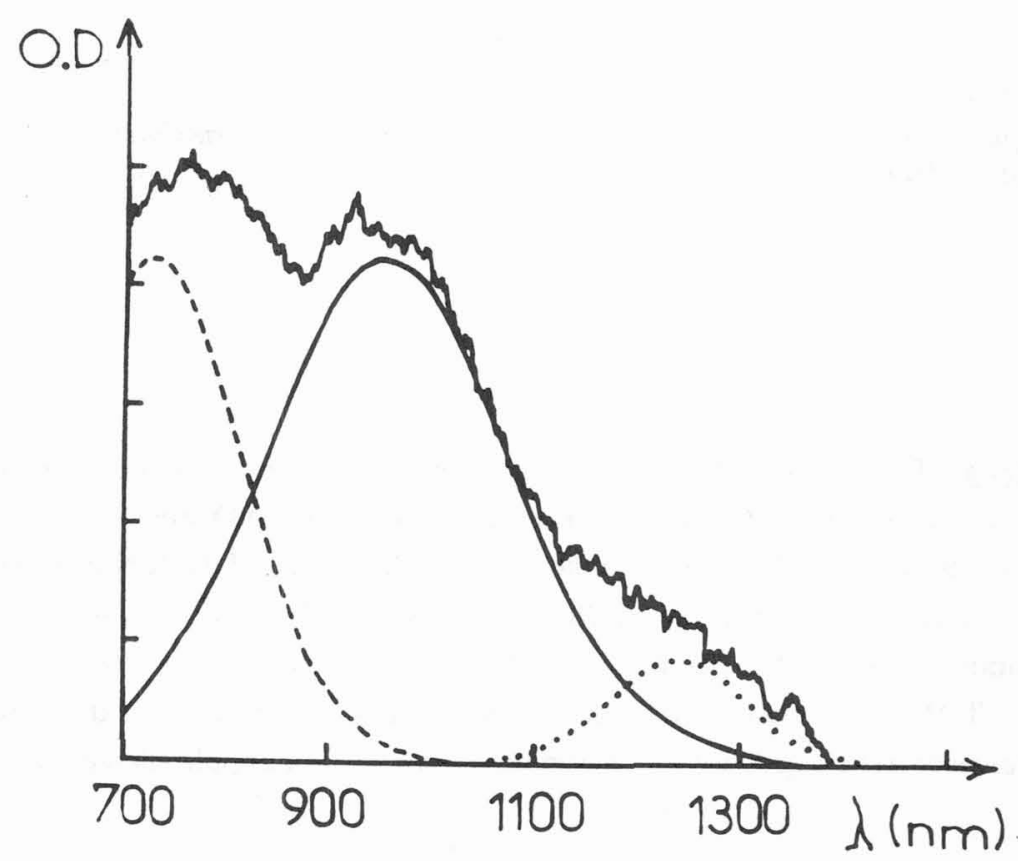

Figure 1 : Diffuse reflectance spectrum of $\mathrm{LaMgAl}_{10.99} \mathrm{Ti}_{0.01} \mathrm{O}_{19}$

Table I : Unwanted absorption bands

\begin{tabular}{|c|c|c|}
\hline & $730 \mathrm{~nm}$ & $960 \mathrm{~nm}$ \\
\hline Dichroïsm & strong & strong \\
\hline $\mathbf{x} \uparrow$ & $\uparrow$ & $\uparrow$ \\
\hline $\mathbf{H}_{2}$ treatment & $\downarrow_{0}$ & $\rightarrow$ \\
\hline $\mathbf{O}_{\mathbf{2}}$ treatment & $\downarrow_{0}$ & $\downarrow_{0}$ \\
\hline
\end{tabular}


$-\mathrm{Ti}^{2+} \mathrm{d}-\mathrm{d}$ transition. The absorption bands would be located at 910,560 and $430 \mathrm{~nm}$. It is not the case

- Intervalence charge transfer transitions : (IVCT).

The existence of $\mathrm{Fe}^{2+}-\mathrm{Ti}^{4+} \rightarrow \mathrm{Fe}^{3+}-\mathrm{Ti}^{3+}$ (as in sapphire (6)) has been proposed but can be discarded because no significant change in the absorption band intensities is observed by changing the $\mathrm{Fe}^{2+}$ or $\mathrm{Ti}^{4+}$ content.

The Ti-Ti IVCT transitions seem the most probable. In this case, the $760 \mathrm{~nm}$ band would be due to $\mathrm{Ti}^{3+}-\mathrm{Ti}^{4+}$ IVCT. This is in agreement with the experimental observations. The $960 \mathrm{~nm}$ band might be associated with a $\mathrm{Ti}^{2+}-\mathrm{Ti}^{3+}$ IVCT. In both cases, the titanium ions of the pair are located in adjacent (4f) sites (face sharing octahedra).

The $730 \mathrm{~nm}$ band can be suppressed by a reducing treatment. However, bleaching of the $960 \mathrm{~nm}$ band requires to prevent the existence of $\mathrm{Ti}^{2+}$. This could be done by a careful adjustement of oxidationreduction treatments.

References

/1/ KAHN, A., LEJUS, A.M., MADSAC, M., THERY, J., VIVIEN, D., BERNIER, J.C., J. Appl. Phys. 52 (1981) 11.

12/ SCHEARRER, L.D., LEDUC, M., VIVIEN, D., LEJUS, A.M., THERY, J., IEEE J. Quant. Electr. 22 (1986) 713.

13/ MONTCORGE, R., Boulon, G., VIVIEN, D., LEJUS, A.M., COllongueS, R., DJEVAHIRDJIAN, V. et K., CAGNARD, R., J. Quantum Electron. 24 (1988) 6.

/4/ MARTINAT, B., LEJUS, A.M., VIVIEN, D., Mat. Res. Bull. 25 (1990) 523.

/5/ MARTINAT, B., GOURIER, D., LEJUS, A.M., VIVIEN, D., J. Solid State Chem. 89 (1990) 147.

/6/ POWELL, R.C., CASLAVSKY, J.L., ALSMAIEB, Z., BOWEN, J.M., J. Appl. Phys. 58 (1985) 2331. 